\title{
CLINICAL OBSERVATIONS ON JAPANESE CEDAR POLLINOSIS
}

\section{By}

SHINSAK HORIGUTI, M.D. and Yozo SAITO, M.D.

From the Department of Oto-Rhino-Laryngology, School of Medicine, Tokyo Medical and Dental University. (Tokyo)

The existence of pollinosis in Japan has been often presumed from various points of view, but very few reports on pollinosis whose allergen is known are found so far. In 1963, in the district of Nikko and its neighbourhood, the authors happened to meet 21 cases with allergic symptoms in nasal cavity, pharynx and conjunctiva, which often appear only in spring season.

Based on various examinations, the authors confirm that these cases are pollinosis sensitized with Japanese cedar (Cryptameria japonica D. Don.) pollen. And this disease is named "Japanese Cedar Pollinosis"

Cryptomeria japonica is a staple forest-tree and is found only in Japan. Its pollination in the vicinity of Nikko and Tokyo is seen from March to April.

From 1963 to 1965, the total of numbers of patients reached 28 cases. The number of the patients increases most at the beginning of April, around when, the number of Japanese cedar pollens dispersed in the air increases most.

The results investigated into allergens in these cases are as follows; Prick test with Japanese cedar pollen showed positive results in $78.6 \%$ of the total of 28 cases. Positive intradermal reactions to the extract of Japanese cedar pollen (Torii Co. Ltd.) were observed in $89.3 \%$ of the total of 28 cases. Positive conjunctival and nasal reactions to Japanese cedar pollen were observed in $89.3 \%$ and $100 \%$ of the total of 28 cases respectively.

In 5 cases Prausnitz-Küstner test were carried out and they showed positive results.

In the stage of attacks, all cases showed eosinophilia in nasal mucus. The nasal mucosa showed swelled ciliated epithelium and abundant goblet cells. There is subepithelial oedema and eosinophil infiltration.

\section{スギ花粉症 Japanese Cedar Pollinosisに関する臨床的観察}

東京医利垱利大学医学部耳鼠咱喉利学教室

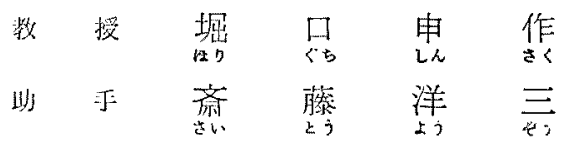

\begin{tabular}{|c|c|c|c|}
\hline & 目 & 团 椎 & 患作数 \\
\hline | & 水えが & VIII 造 & 伝阙俰 \\
\hline I & $\begin{array}{l}\text { スギ Cryptomeria japonica D. Don 招上びそ } \\
\text { の化粉 }\end{array}$ & 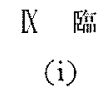 & 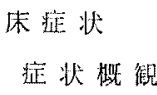 \\
\hline II & 観察対缘 & (ii) & 㩊 鿊 状 \\
\hline VV & 発生约 & (iii) & 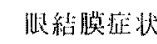 \\
\hline$V$ & 婃発洔期 & (iv) & 咆晆頭症状 \\
\hline VI & 年令叔上び姓別 & (v) & 消化器匴致 \\
\hline
\end{tabular}


(vi) 神絟症状

(vii) 全身症犾

X踟床程過

X皮虎区灾

(i) 花粉による乱刺法

(ii) アレルゲンエキスによる単刺沾

(iii) アレルゲンエキスによる汥内区灾

XII Prausnitz-Küstner 反応

XIII粘膜反応

(i) 鼻粘㷬反応

(ii) 腿結膜反応

XN 好 酸 球

(i) 奥汁中好酸球

(ii) 末梢血中好酸球

(iii) 組織中好酸球

(iv) 誘発武験の際の好酸球の動態

XV 病理組織学的所見

XV 症例の観察

$X V I I$ 治 療 法

XVIII 総 括

$X X$ むす び

\section{Iまえがき}

今日，欧米諸国に拈いては極めて多数の枯草熱 Hay Fever の患者が存在し，その原因の大部分が 空中に飛 散する各種草木の花粉であるとされている，花粉が原 因の易合この枯草熱は花粉症 Pollinosis とも言われる が，この花粉症は，わが国に利いては奏際に患者が少い のか，或は検索が不充分なためか，従来稀なる疾患であ るとされてきた。しかしがら近年，空中飛散花粉の研 究も行われるようになり，その結果わが国に虬いても米 国と同しく，空中飛散性の花粉には季節的な特徽があ ク，ほば 3期すなわち, Tree Season, Grass Season, Ragweed Season が恐められるよらになつた。 さらに 米国に括ける枯草熱の最大の原因であるブタクサ属を例 にあげても，わが国にる地域によつては相当数との花粉 の飛散をみて和り，そのアレルギーの存在も十分考えら れてきた。

一方各種アレルゲン抽出液による検査法にも進歩が諗 められ，その結果近年，実際にブククサ花糃による花粉 症の存在は確拣視せられるようになつたが，その他の北 粉については，フレルゲンとしての確定を欢たものは少 くなおアレルゲンの険案には困難を伴つている、数全 来, 著者らはフレルゲンの検索をも含めて, 鼻アレルギ
一の臨床的研究を行つてきながたまたま昭和 38 年春， 枋木県日光地方において，季節性特に 春季に迊る，畄 腔，咽頭並びに眼結膜のアレルギー症状を呈する21 例 の患者に遭遇した。これらに対し各種のアレルギー学的 検索を行つた結果，これらの症例がスギ Cryptomeria japonica D. Don の花粉をアレルゲンとせる花㸮症で あることが確認されたので，これをスギ花粉症 Japanese Cedar Pollinosis と命名し，第13 回日本アレルギ 一学会総会, お上び第 65 回日本耳與咽知科学会総会に 颃いて発表したが，その後症例它增加し，日光地方以外 においても広く患者の発生を確認できるよらになつた。 ここにスギ花粉症に関する臨床的観察を行い，花粉症に

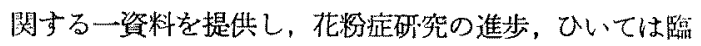
休アレルギー研究の進歩の一助亡したい、

\section{II スギおよびその花粉}

スギ Cryptomeria japonica D. Don は裸子植物門， 球果植物絧，マッ目，スギ科属する植物である，日本 の特産であつて, 北海道を除き全国各地に野生が办られ るが，また広く植林もされている。雃雄同株，花は早春 に開く. 婎花は長さ $6 \sim 9 \mathrm{~mm}$, 直径 $3 \mathrm{~mm}$ 位の小棈円 形をしていて，枝の端に群生する．花枌はこの雄花に ある。雌花は緑色で球形をしていて，小枝の端につく。 若千の林業上の変種はあるも, 植物学上では一種に限ら れている、花粉の形態については，花将型は球型，大き さ $25-29 \times 25-29 \mu$, 花粉管口は単口で突出, この突出 部が鈎状に曲つているのが特㨖である。

標本製作の際，膨発して内容物を吐出しているものも あり，この場合は花粉膜たけが色素で染色される。な和 花粉の染色に用いられる色素は，フクシン。ゲンチアナ 紫，メチレン青等であつて，花粉はこれらに対し正染色 性を有し，簡単に染まる，写点 $1 ， 2$ はスギの婎花の開 花状態と，スギの花粉の顕微鏡像である。

\section{III 観 察対象}

スギ花粉症の症例は現在までのところ総計 28 例で， 内訳は栃木県日光市の古河電工日光電気精銅所附属俩院

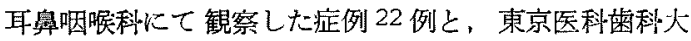

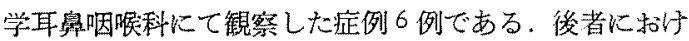
る地域分布は，東京 3 例，神奈川，荻城，埼玉各 1 例で ある。

\section{IV 発生頻度}

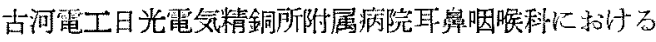
観祭結果を述べる.1963年度に和けるアレルギー怪鼠 炎患者総数 33 例の月别発生頻度は第 1 㘠の如くである 
写真 1 スギ Cryptomeria japonica D. Don の维花の開花状態

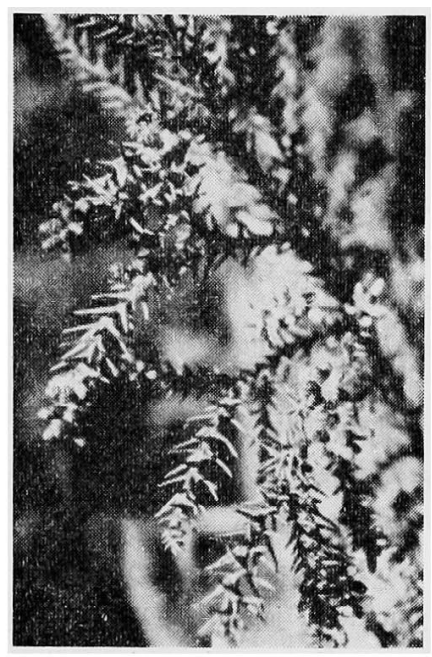

写真 2 スキの花粉 $\times 400$

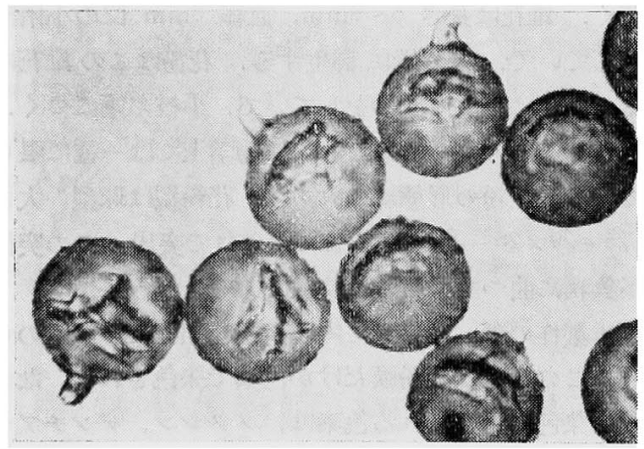

第1図アレルギー性鼻炎（スギ攸粉症を含む）

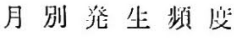

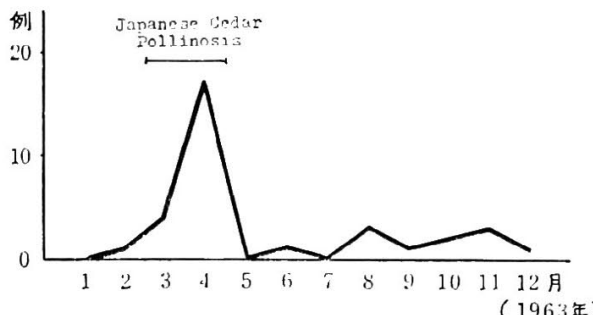

第 2 図栃术県日光地方に括ける 贫中飛散化粉数の梌案（1964 年）

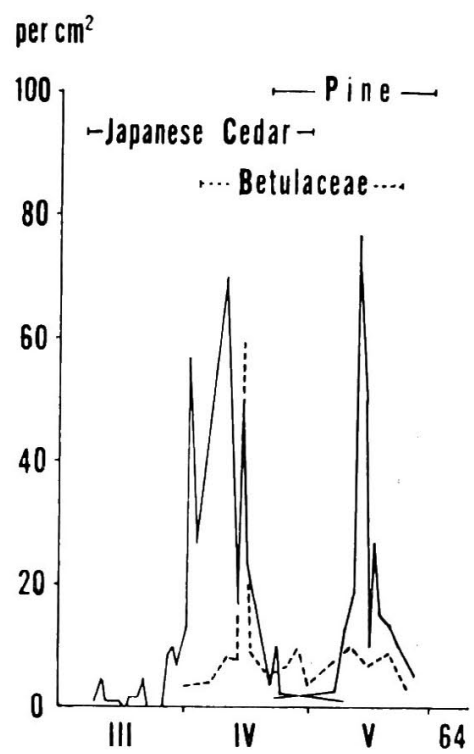

第3 図 東京都日黑区に拈ける 望中飛散花粉数の㭘索 (1964)

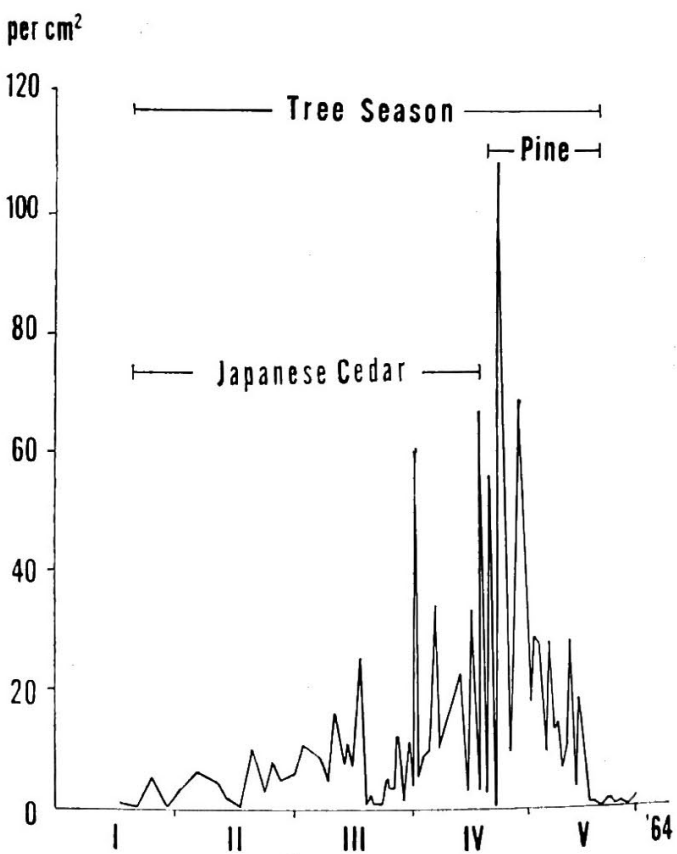


が，3月と4月に括ける21 例がスギ北溇定である。し

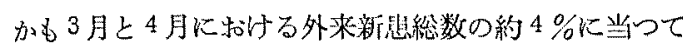
いる.

\section{V 好 発 時期}

一般に花粉症の発症時期はその原因植物の開花時期に 一致寸る、本症に括いても同様である、スギの如き風媒 花の開花期間は空中飛散花粉数の湘定之, 直接の観察に よつて判明するが，日光地方に怙けるスギの開花期間は

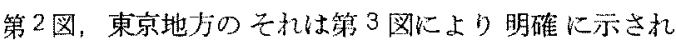
る.いずれとしても本症の好発時期ならびに症状の発現 期間即ち発作期は通常 3 月と 4 月に限られている。患者 発生数は空中飛散スギ花㸮数が 最高に達する時期即ち 4 月上旬が最高になる。るつともこれらは年によつて多少 の差が存在する。

\section{VI 年令および性別}

性別男 17 例，女 11 例で多少男に多い，発病年令は 男女とも20３0 代の青年期に多発している（第 4 図).

\section{VII 罹病年数}

発病後 2〜3 年経過している者が最も多い 日光地方

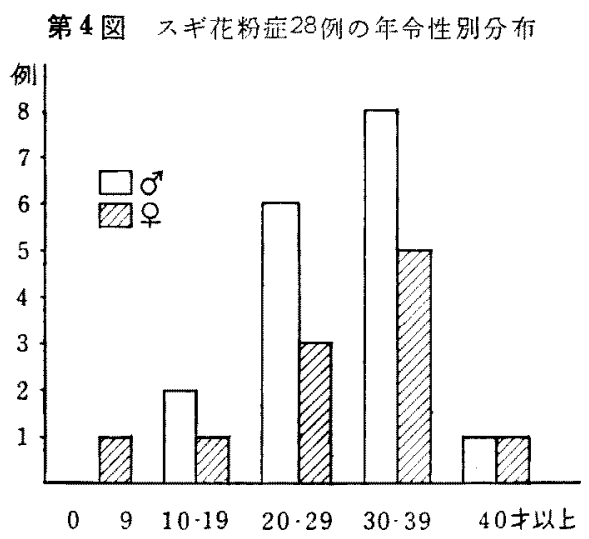

第 5 图日光地方に居住してから発病までの年数

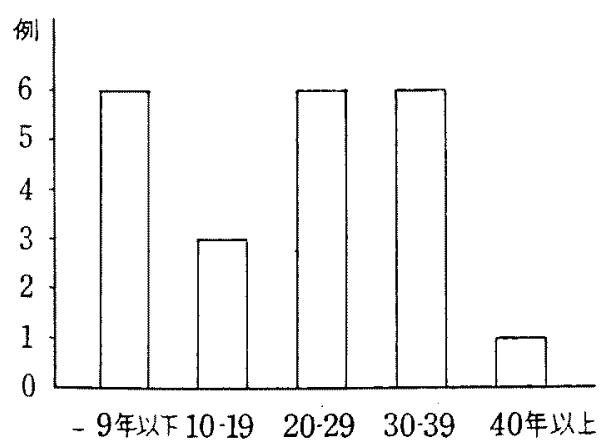

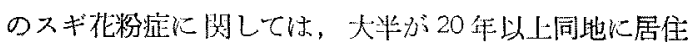
してょり発放している(第5图)。ただしアレルギー体 韻と思わ祅る者が東京より日光に移住して $3 \sim 4$ 年の短 期間で発病した例もあるが，一般にはスギの花枌纪上る 感作は永年かか心て成立し発病侄るもののようでる る.

\section{VIII 造伝関係}

本拉罪患の者には，既往並びに合併拉にアレルギー性

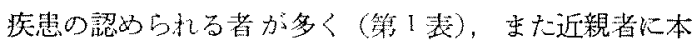
症怆いが，家族歷他他のアレルギー性疾患の認められ る者が多く(第 2 表)，「レルギ一素質が本疗の発生に ある程度閂与するもの上思わ饥る。

第 1 表 他のアレルギー性疾患の既往 あるいは合㭛

\begin{tabular}{|c|c|c|c|c|c|c|}
\hline \multicolumn{6}{|c|}{ 他のアレルギ一性疾患 } & 例 数 \\
\hline 藤 & & h & & & 疹 & 3 \\
\hline 湿 & & & & & 疹 & 1 \\
\hline 父 & 管 & $\bar{z}$ & & 喘 & 息 & 1 \\
\hline 接 & 触 & 性 & 皮 & 籍 & 炎 & 1 \\
\hline & & & & 計 & & 9 \\
\hline
\end{tabular}

第 2 表 家推歷にみられた アレルギー性疾腎

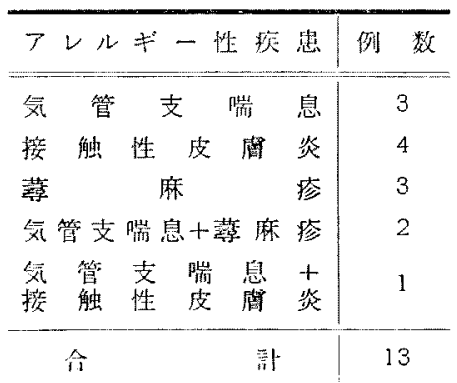

\section{IX 臨床症状}

（i）症状概観定型的な花枌症には，症状の発現す る発作期と，全々無症状の閌歇期とが認好られる。一般 に花粉症の原因植物は之の植物に決つた開花期を持ち，

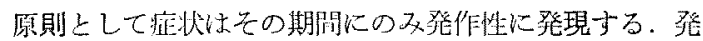
作後また怯間歇期にはなん等の後遗症を残さない，花将 症発作の主症状は毀腔おょび咽頭粘膜の症状々眼結膜症 状である，症状は花粉との接触後数分以内に発現する。

代表的な症状はまづ舅腔内に瘦样感があり，〈しやみ 


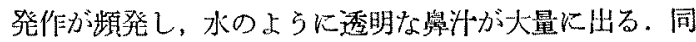

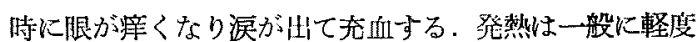
で平熱の場合が多いが，全身汇熱感を感ずる場合もあ る、くしやみ発作のあとはしぱしば帠閉をきたし，完全 に閉塞し口呼吸を余旌なくされる場合もある。これらの 発作は開花期間中続きその終了とともに発作孔漸汽弱く なつて全く終息してしまら。不化粉痱の臨床症状を第 3表沶示时。

第 3 表

嚳 症 状…................................28 例

鼻内瘦棒感

くしやみ発作

水棣性鼻漏

奥閉

鼻前庭発疹

腿結膜应状 25 例

眼結膜湍嫊感

流滬

哏脂

蓋旦

異物感

哏瞼腫脹感

咽喉頭症状 7 例

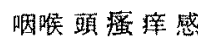

刺激性登発作

消化器障書 5 例

胃部膨满感

放屁

唾济過分泌

神経症状 5 例

頭

痛

全身症状

$\begin{array}{lll}\text { 熱 } & & \text { 感 } \\ \text { 㑫 } & \text { 导 } & \text { 感 } \\ \text { 脱 力 } & \text { 感 }\end{array}$

(ii) 鼻症状 鼻症状について詳維を述べてみると， 花粉との接触があつてから症状発現东での時間は誘発試 騒によのて観察したところによると数分以内である。ス ギ花粉の開花は一般に日の出から早朝にか子て始まり， 湿度が低下するとともに空中に飛散するスギ花粉は增加 する．從つて発作わ早朝に始まることが多い，始めは鼻 腔の瘦癍感が起り，続いてくしやみが頻発する，同時に 大量の水棣性の鼻汁が流出寸る：この鼾汁中には多数の 好酸球が含まれている。
この際曒腔战莫は始めは発赤性に腫脹しているが後に 蒼白浮腫状亡なる場合もある。このために秵腔は閉塞し て鼻で呼吸することが困難となる。特に夜閒はこれが著 しい。時に鼻前庭の皮慮に皮盧炎様の発惨をみることが あり，この症状も鼻粘膜症状の消退と共に消失する。

(iii) 腿結膜症状化粉の接触より症状発現までの 洔間的関係は鼻症状と同じである。一般的には眼結膜症

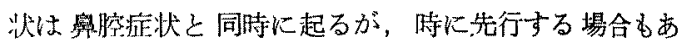
る. しかし発作開始後数日経過してから雨症状が揃ら場 合が多い，発作が起ると腿結膜に瘦群をし，涙が流出 する，時に眼瞼が腫脹し，粘液性の眼脂の敗溜をみてこ の中心好酸球を諗める．あるいは美明，異物感を訴える 場合がある，眼臉結膜と眼球結膜の特に内眼㑇附近に充 血をみる例が殆んどである，著者らはこれらの自他覚的 所見がいかゆる急性春季カタルと全く同じのと考光て 扣り，従来言われている急性春季カタルの花粉感作説を 花粉症の立場より立証したるのと考える．更に著者らは 春季に発症し，従来急性春季カタルと診断された結膜炎 の大多数はスギ花枌によるアレルギー性結膜炎で，スギ 花粉症の一分症であるらと考市ている。

(iv) 咽脆頭症状 やはり花聁か接触することによ

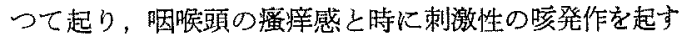
場合がある。この他夜間の鼻開のため口乎吸を余苸なく され，このため起床時に咽頭の乾燥と疼痛を訴克る場合 が多い.

（v）消化器障害 番腔咽頭に接触した花粉が悲下 されて起るフレルギー性消化器症状で, 胃部膨満感, 放 屁，俥液過分速などがみられる。

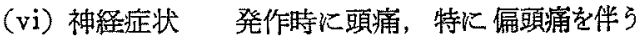
ことがある。

（vii）全身症状全身の僚怠感亡脱力感を訴兄る場 合むあり，また著明な発熱はないが，多少の熱感を伴う ことがある。

\section{X 臨床释過}

一般に花粉症の絽過には若干の個人差があるが，こん は個人の花粉に対する過敏性の強弱之，空中に我散する 花粉量の多少に関係するためである。花粉の開花期も年 により若干のずれがあり，従つて発作の始まる時期にる ずれがある訳である。一般にスギの開花期は前述の如 々，東京地方に扣いては 2 月から4月であり，栃相月 光地方に放いては3月から4月であるが，年により5月 に及ぶ事もある，空中飛散花粉数が最大に達した時期に 症状は一番昰化する。この時期は4月上・中旬である場 
合が多い，開花期の終了とともに，症状は消退していく が一般には多少長びくのが通例である，これには二次感 染の存在も考兄られ，あるいは又すでに屋外及び屋内に 落下せる花粉が再び空気中に飛散し，それとの接触の可 能性も十分考えられる，一般に一日の内で発作の頻発す る時刻は原因植物の開花時刻之関保がある。スギの花粉 ではその飛散数は湿度と最も関係が深いことはすでに前 論文で述べたが，一般に日の出後に湿度が急激に下り， これとともに花粉の飛散数が上昇し，午前中に最高とな るようである。そとて日没後湿度が急激に上昇するまで 飛散が続くため発作も日中に頻発する。睛天，強風の日 恃花粉の飛散も多く，そのため症状は婜化する.

あるいは寒冷前線の通過の際には，湿度が急湤に下り

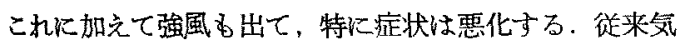
象の変化，特に前線通過の際にある種の疾患が增悪した り，発作が起きたりする場合がある事がいわれている が，少くともアレルギー性上気道疾患以関してはここに 述へたよらな事実がその現象の一端を解明するものと考 点ている，最天および雨天には湿度之降雨による花粉の 降下のため, 空中飛散花粉量が減少し, 従つて発作が少 〈なる.

\section{XI 皮店反応}

フレルギー性疾患の蹦床診断の目的にしばしば使用さ れる方法であつて，アレルゲンと目される物質を作用せ しめ，一定時間啳に起る皮膚の反応を調べ，或る程度以 上の発赤，膨疹形成をるつて陽性とするが，その判定に は傎重な考慮を必要とする，必ず対照試験を行うべきで ある。

（i）花粉に上る乱刺法 スギおよびこれとほとんど 同時期汇開花するか心ンキ属，ヤナギ属の花粉をのるの を使用した，方法は前腕内側皮膚に一滴の生理的食塩水 を滴下し、これに微量の花粉を付着させ，直径 $0.5 \mathrm{~cm}$ 円内泛ほ济均等に 10 回乱刺する. 判定は 20 分後の所見

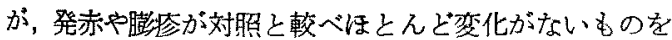
陰性とし，対照比して明らかな膨疹や発赫は認められ

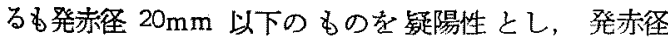
$21 \mathrm{~mm}$ 以上の子のを陽性と乙た。

成績は第 4 表の如く， スギの花粉に対し 28 例中 22 例 $78.6 \%$ が陽性，残り6例は疑陽性であるが，対照之他の 花粉ではいずれる陰性であつた。

(ii) アレルゲンェキスによる単刺法アレルゲン エキス「トリキ」のスギ花粉 エキス 1000 倍， 100 倍， 10 倍液によつて乱刺法を行つてみたが，1000倍液と100
第 4 表 各種花粉による乱刺法陽性率

\begin{tabular}{|c|c|c|c|c|}
\hline$\neq$ & カバキ属 & ナナギ属 & 対 & 照 \\
\hline $\begin{array}{c}22 / 28 \\
(78.6 \%) \\
\text { 性 }\end{array}$ & 陰 & 陰 & 除 & 性: \\
\hline
\end{tabular}

倍液についてはほとっど刘照と変らず診断的意義を認め なかつた．10倍液については12例中9例に和いて対照 に比し腰疹，発赤の掂大をみ，スクリーニングテストと しては意味があると思われるが，非实用的であり，次に 述べる皮内反応の診䉼的価値见勝る点住認わられなかつ た。

(iii) フレルゲソェキスによる皮内反応一般にア レルゲンの決定にはアレルゲンェキスによる皮内反応が 最も多く利月されている。ここではナアレルダンエキス 「トリキ」1000倍液の $0.02 \mathrm{ml}$ 前腕内側记皮内注射 乙，15 30 分後に扣ける反応を欢て，発赤 $20 \mathrm{~mm}$ 以上 或心膨疮径 $9 \mathrm{~mm}$ 以上のいずれかの条件を满足すれば 陽性と判定した。

主なる吸入性アレルゲンエキスとして、スギ、ブタク サ，アカマッのそれぞれの花粉と室内栕の4 種を選び皮 内反応をみたが，その結果は第 5 表の如く，スギに対し ては 28 例中 25 例 $89.3 \%$ が陽性で, 残り 3 例は疑陽性

第5表 吸入性アレルゲンェキス皮内反芯陽性率

\begin{tabular}{c|c|c|c|}
\hline ス & ブターサ & アカマッ & 空 内 \\
\hline
\end{tabular}

第 6 表 柘木罢日光地方に乱けるスギ花物症の 皮内反底重複隄性現象

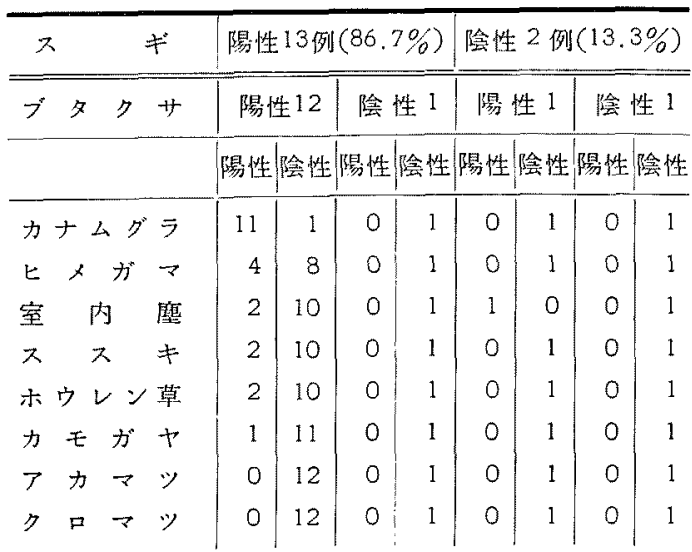




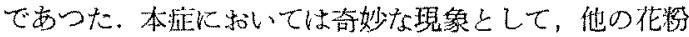
エキスと重椱して陽性を示す場合がみられる，第6表は ブタクサの非繁策地である日光地方に执けるスギ花粉症 15 例飞施行した皮内反広で重椱陽性現急を示したもの

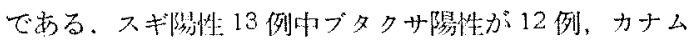

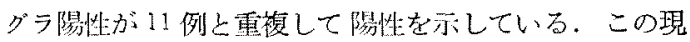
象共，共通抗原の存在，古るは各フレルケンに対し全 く别個に感作せられたるのか，あるいは維にハランルルギ 一として䚌明するた゚げよいものか，種々な可能性方洘 えら机るが，とに解ブタクサ，カナムグラ等がこの上う に陽性に出るのではアレルゲン检索上不都命である、畒

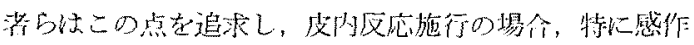
力が㧧い花汾の抽出液の濃度は現行の1000倍液では不 適当で，更に希积し 50 万倍，100 万倍といら低䀼度の 液を使用す心゙きで，かくすれ㤹従来の陽性判定基準のま まで手重復陽性の現象を防处でき，少くとも現在以上に 真のフレルゲンの检索が容易になるものと考光ている。 しかしながら少くともスギ花粉エキスに上る皮内反応の

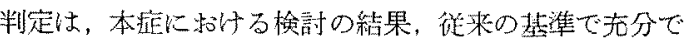
あることがわかつた。

\section{Prausnitz-Küstner 反枕}

花粉の如き财入性アレルゲンの自然的感作によりつく られる抗体は, Coca 拈上び Groveにより atopic reagin あるいは粆に reagin 乙名付けられ，しか舟感作 されている腎者血清の passive transfer により正学者 に移行させることができる．Prausnitz-Küstner 反応 はこの reagin の存在を証明する基檚的な方法であつ て，患者血清 $0.05 \mathrm{ml}$ を皮虞反応陰性の被换者 (Recipient）の前腕皮内に注射し，この部位に24 48 㭙間媛 にアレルゲンエキス $0.05 \mathrm{ml}$ を再注射 (Challenge) す る。本症の5例に施行した結果は，全例に括いてスギ花 粉エキスに対して陽性であつて，患者血清中に reagin の存在することを証明した。

XIII 粘膜反必

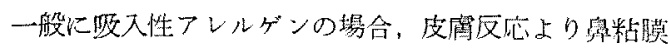

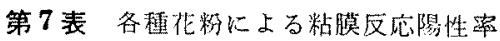

\begin{tabular}{|c|c|c|c|c|}
\hline & 粘 & 膜 & 底 & 結搭反応 \\
\hline$x$ & $\neq$ & カバノキ鼠 & ナナギ㟲 & ギ \\
\hline \multicolumn{2}{|c|}{$28 / 28$} & \multirow{2}{*}{ " } & \multirow[b]{2}{*}{ " } & \multirow{2}{*}{$\begin{array}{c}25 / 28 \\
(89.2 \%)\end{array}$} \\
\hline & & & & \\
\hline 陽 & 性 & $P_{2}$ & 除 & 愔 \\
\hline
\end{tabular}

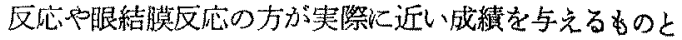
考えら礼ている（第7表）。

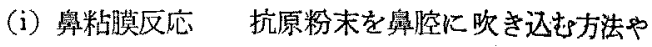
抗原液でしめた綿を鼻粘膜に貼布する方法等があるが， ここでは花粉そのものを雨方法で使用し，不ギ花粉では 全例に鼠アレルギー症状の発作，すな的ちくしや愽

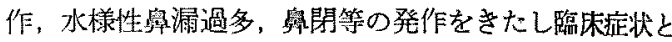
全く同様の症状の誘発以成功した。これに反し力ハノキ

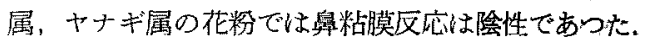

(ii) 腿結膜反応桠く微量の花粉を内眼角部の眼 臉結膜に附着させ，瘦瘈感，充血，浮腫を示す場合を陽 特之判定した．その結果スギ化粉に刘し，28 例中 25 例 89.3\%に陽性の成續を得た。

\section{XIV 好 酸 球}

アレルギーに打ける好酸球の診断的価値は現在広く認 められる傾向にあり，特に舅汁中の好酸球增多について は，Hansel を始わ多数の者加その価檤を高く評洒して いる、本症の如き花粉症はアレルギー性疾患として定型 的な子ので，本症に和忷る好酸球の钼察にこそフレルギ 一と好酸球との問題を解明する糸口が存在するものと考 るられる、すでに著者らは前論交において，花粉症に招 ける时酸球の動態について記载しているが，本幊では特 にスギ花粉拝に関する事項の文を要的して述べ。.

(i) 鼻汁中好酸球発作期には 鼻汁中好酸球增多 $(>5 \%)$ は必発の現象であつて全例認められ，これが 間歇期になると翟められなくなる。これがまたつの特 徽である。

(ii) 末梢孟中好酸球発作期には必ずしも好酸球 增多(>400/ $\left.\mathrm{mm}^{3}\right)$ 㠻示す訳ではないが，すでに前諭 文で詳速したごとく，殆えどの例に括いて，発作期には 間歇期の平常レベルよりも增加していることが判明し t.

（iii）組織中好酸球同一患者の発作期上間歇期に

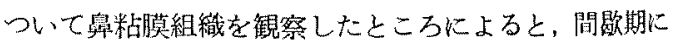
末梢伹中好酸球数 $200 / \mathrm{mm}^{3}$ で粤汗中好酸球增多を認め す，しか子中鼻介粘膜には好酸球が殆儿ど諸められない 症例が，発作期では末柏血中好酸球数は $445 / \mathrm{mm}^{3}$ とな

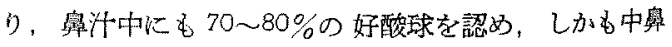

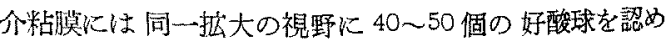
るよらになつた。これらの事丰上り好酸球が抗原抗体反 応に括ける不可欠な細胞要素の一つであることが爝床的 にも証明されたものと考点る。

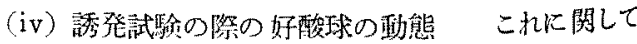


も前論文で詳述したが，いずれる間殿期にアレルギー発 作を再現せしめ得て，しかる末梢血中ならびに鼻汁中好 酸球が著明增加する. 従つてこの事実からも好酸球が 抗原抗体反応に批る不可久な細胞要素の一つであるこ とが証明され，しかもアレルギー発作時に括ける好酸球 の変動の観察に診断的価值のあることが知れた。なお症 状の軽重と好酸球增多の程度とは特に関係はなかつた。

\section{XV 病理組皏学的所見}

本症の発作期に括ける鼻粘嗼の組織学的特㠎は，血管 の㹡張，それに伴う浮遁等の機能的变化と，好酸球を始 めとする各種細胞成分の增加である．しかもこれらの変 化住いずれも可逆的であつて，間歇期には正常鼻粘䠑組 織に復するのが通例である. 先つ上皮細胞は膨化し無線 毛となる場合が多く，杯細胞は增加する，病变が高度に なると上皮細胞の一部は剥脱し，場所によつては基底細 胞のみとなり，全体として上皮細胞の配列が 不揃とな る. 特徽である血管の执張は浮尰を伴い主として上皮下 組織に著明で，またここに著明な好酸球の潤がみられ る. 特に上皮層の直下と血管周囲に著しい，好酸球の遊 出が上皮層内にみられる場合もある．好酸球以外にリン 球，単核球，形質細胞などるみられる，かかる病変は 可逆的であつて，基底膜の肥厚，血管壁の膨化，線維素 様変性等のいわゆる慢性のアレルギー状熊の皇粘膜にみ られる如き变化は発現しない。

写真 3 は発作期比和的中番介粘膜の組織像, 写真 4 は間歇期における同一患者の中鼾介粘膜組織像である. な扮花粉症の粘膜病理は動物実験をも含めて目下さらに

写真 3 発作期の中身介粘膜組織像

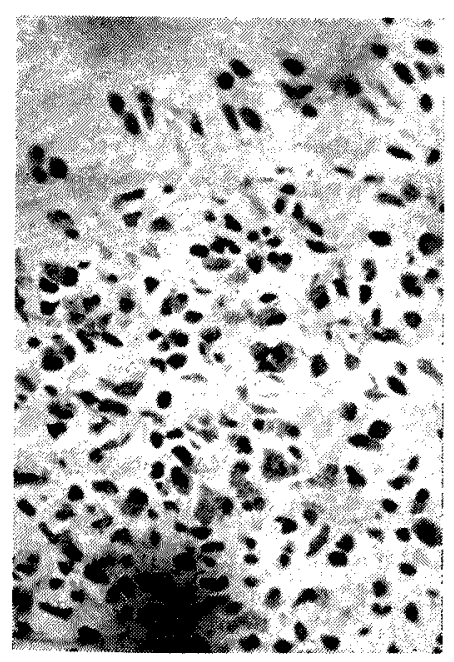

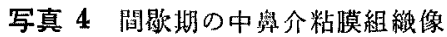

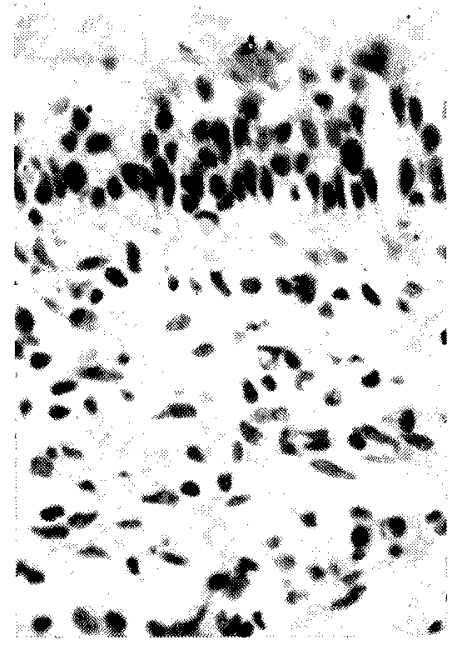

研究中である.

\section{XVI 症例の観察}

以上の如くスギ花粉症に対する種々の綜合的観察成續 について述へてきたが，本項では典型的症例について各 種のアレルギー学的検査成績と臨床経過について詳述す る.

症例 松○静○ 女, 32才, 主婦, 日光市居住.

既往歴，家族歴には気管支喘息，薄麻疮等のフレルギ 一性疾患があるが，本人には認められない，生来日光に 居住し住宅は杉植林地域に比較的近接している.

現病歴，38年 3 月上旬頃上り昼間眼結膜滛感を時 タ 認めるようになつた。 ○月下旬頃よりはこれに加えて起 床時に頻回のくしやみ発作があり，水梯性鼻汁を出し， 更に眼症状も櫁痒感の他, 流涙, 眼脂なども認める上う になつた。特に4月上旬から中旬にかけては，番および 眼症状が悪化し，特に夜閒の完全なる鼻閉のため起床時 に咽頭の乾懆感，疼痛などを感ずるほどであつた，発作 の著しい時炕全身も何となくだるく熱があるようで頭 痛がする．以上の諸症状をるつて昭和 38 年 4 月 20 日， 日光電父精銅所病院に来院した，嶴腔所見では，中鼾介

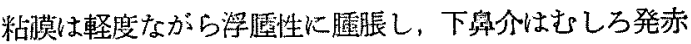
気味であつた，番分泌物は樂液性である，レ線学的には 副冏腔に陰影は認めない，眼結膜所見では内眼角部の眼 瞼扣上び眼球結膜に充血を認めた。他には特に異常所見 はない，アレルギー学的検查は第 8, 第9表のごとく で，特に皮内反応に打いてブタクサ花粉，不キ花粉エキ スに陽性であつた， $\mathrm{P}-\mathrm{K}$ 反応も雨エキスで陽性であつ 


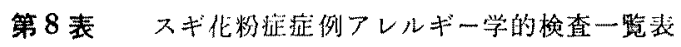

1. 皮盧反応

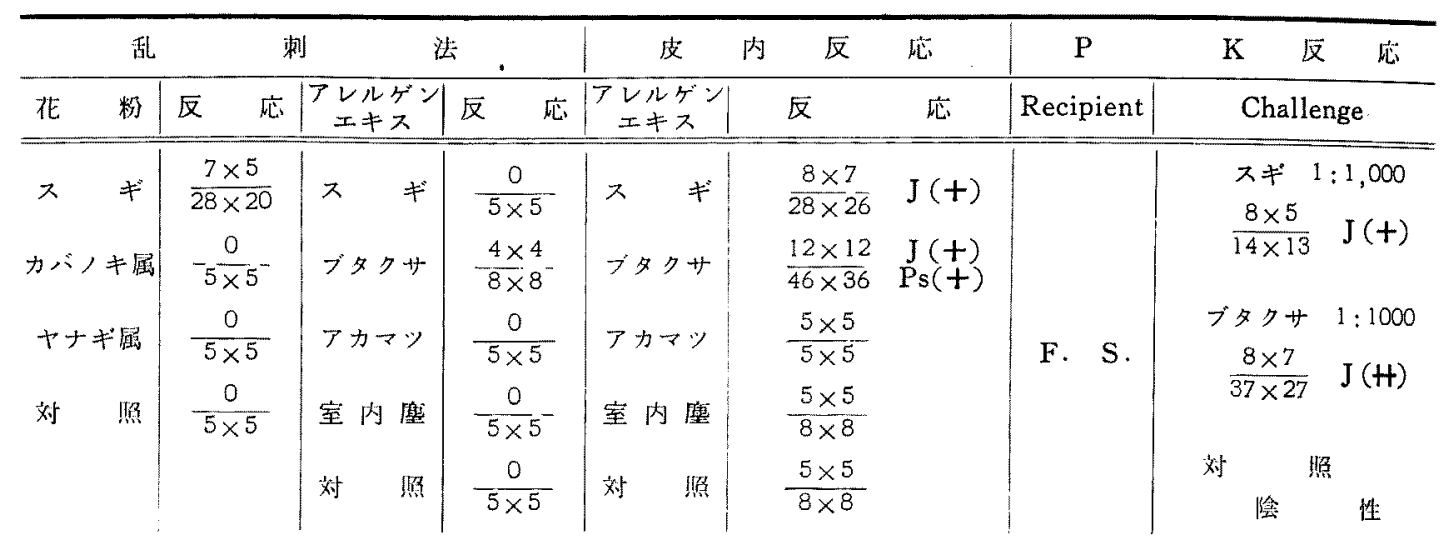

第 9 表 スギ兆粉症症例アレルギー学的检査一筧表 2 粘膜 区 応

\begin{tabular}{|c|c|c|}
\hline 花 粉 & 奥粘膜反応 & 眼結膜反応 \\
\hline x & + & $H$ \\
\hline カバノキ属 & - & - \\
\hline ヤナキ盘 & - & - \\
\hline 刘 & - & - \\
\hline
\end{tabular}

3 Eosinophils

末梢䁬中 Eos.

$1181 / \mathrm{mm}^{3}$

與计中 Eos. $100 \%$

組 穖 中 Eos.

多数

た. 粘膜反応は花粉そのものを刚いスギ化粉に特哄的に 陽性の結果を得た，好酸球については，末梢血中，畺中 汁ならびに組織中好酸球の検索を行い，いずれる著明な 好酸球增多を示した. 以上の如く本症例は発症 1 年目の 患者であるが定型的スギ花粉症の症状ならびに所芫を示

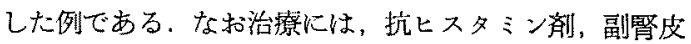
留ホルモン等の薬物療法を行つたが效果は一時的に過ぎ なからたようである。その内スギの開花期間も過ぎ 5 月 上旬頃には自他覚所見は改善され，5月中旬頃にて殆ん ぞの挂Uは消退した。

\section{XVII 治療法}

スギ花粉症を発見した昭和 38 年については，刘拉撩 洗のみとし，抗ヒスタミン郕，副腎皮質ホルモン等の投 与を行い，一畤的には症状の改善をみた。たたしこれら の療法はあくまでも対症療法に過ざず、投楽中止によつ て再然与る。
またこれら薬阁の長期使用にはそれぞれ何らかの副作 用もあり，治療法に関しては結局のところ根本的療法の 確立が期待される訳である。そこで現在抗原の明らが された花粉症の治療法として一般に最も期待されている のが減感作療法であるが，我国に特いては未だその確立 をみておらず，ての成瞔も不定である、そこで著者らは 以前よりフレルギー性鼻炎特に我国に执いては最す多い 抗原不明な例に対して，同時に潜在する䙹咽非炎の治燎 を行い，良好なる治療成續を絽験しているが，スギ花枌 症に刘してもこれを応用し経過を観察している，勿論ス ギ花粉エキスによる減感作療法る独自の方法を考古施行 しているが，現在までのところ兩治療法とも列数が少く な扣長期に放たる観察が必要上考光，今後の研究課題と している．北粉应の治㙩浩に関しては追つて発表する予 定でいる。

\section{XVIII 總}

括

スギ化粉辌 Japanese Cedar Pollinosis は，スギ Cryptomeria japonica D. Don の化粉に感作された個 体が，スギの開花期間にほぼ一致して，即ち3月および 4月にか计て，スギの花粉を吸入することにより発病す る、青年期に好発し，多少男に多い上5である。またあ る程度アレルギー素因が発病に関俰する。䁂休定状は，

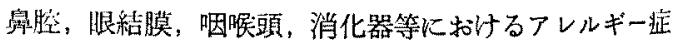
状が主体となる。臨床績過はスギの開花期間が終了して む多少延長して 5 月に及ぶ場合がある.症状の程度は空 中飛散花粉量に関係する、診断は詳細なる病歴の聴取 と，皮膚反応，P-K 反応，粘膜反応による誘発試験な ぞによつて行う、補助的には好酸球の測定によるてレル 
ギー状態の検索が必要である．治療法としては，抗ヒス

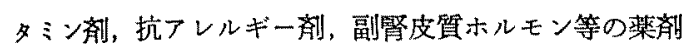
浪一時的効果を期待するのみである。減感作療法による 持続的効果も期待できるが，同時に存在する鼠咽詝炎の 治療が必要である.

\section{XIX むす び}

著者らは昭和 38 年 3 月杤木県 日光地方においてスギ 花粉症 Japanese Cedar Pollinosis を発見して以来花 粉症に関して各種の研究を行いらつあるが，本論文はス ギ花粉定に関する現在までの臨床的観察を総括したもの である。

従来我国において花粉症は，その基礎的ならびに臨床 的研究の不足から極めて稀な矮患之され，成書の記載も 外国交献によるのみであつた．近時ブタクサ花粉症につ がいてスギ花粉症が発見せられ，加らるに各種の牧草に よる花粉症も報告せられるに及び，花粉症は臨床アレル ギーの方面からアレルゲンの確定せられた典型的なフレ ルギー性疾患の代表として特に注目を浴びてきている。 ことにスギ花㸮症は純日本的な花粉症として内外上り與 味を引くるのと考えている.よつて著者らは花粉症こと にスギ花粉症に関する今後の研究課題として，基礎的事 項では兔㾤血清学的砳究, 臨床的には治療法に関与研 究等を計画し，目下研究続行中である。

\section{文献}

1) Berendes, J., Link, R., and Zöllner, F.: Hals-Nasen-Ohren-Heilknde,Bdl, 377, $1964 . \quad 2)$ Hansel, F.K.: Clinical allergy. C.V. Mosby Company, St. Louis, 1953. 3) Hara, H.J.: Hay fever among Japanese; I, Arch. Otolaryng. 20, 668, 1934. 4) Hara, H.J.: Hay fever among Japanese; II, Arch. Otolaryng. 21, 9, 1935. 5) Hara, H.J.: Hay fever among Japanese; III, Arch. Otolaryng. $30,525,1939$. 6) Horiguti, S., \& Saito, Y.: A new treatment of nasal allergy Bull, Tokyo Med. Dnt. Univ., 10,1, $1963 . \quad 7)$ Voorhorst, R.: The eosinophil cell and its role in allergy and infection, Rapp. III, 7e Congr. int. Oto-Rhino-Laryng., Paris 1961. Adv. Oto-Rhino-Laryng., Vol. 10, pp. 86. 8) Wader, A.. Diagnostik und Therapie der allergischen und extraallergischen vasomotorischen Rhinopathie, Plactica Oto-Rhino-Laryng. Suppl. Vol. 24，1962.99) 青木已三男： 諸種の花粉炕因る実 弱的過敏性現象の研究，成医会誌，60，1124，1941. 10) 天柇景康：枯草熱汇関する病原植物之簢易特異性

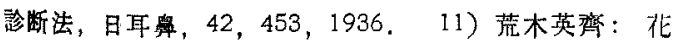

粉症の研究，I アレルギー．9(8)，648，1960，12) 荒木英斉：花粉症の研觉，\|，アレルギー, $10(6)$,

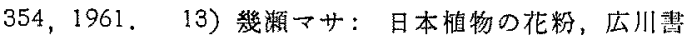
店, 東京, 1956. 14) 狌濑 ついて 植物研究誌，37，2，1962，15）幾敉マサ他： 東京，大阪，福岡に捕ける空中飛散花粉について，生萩 学雑誌，18，1，5，1964。16）池田正男：化粉「了 レルギー」の研㠰，鹿応医学，18，10，1153，1938.

17) 石井英男：可舆疾患とアレルギー、アレルギー，金 原出將, 東京, 407,1958 １8）石畸達：化粉アレル ギー，フレルギー，金原出版，東京，218，1958，19） 岩波洋造：花粉，共立出股，1956。20）川上保焳： アレルギー性疾患の診断，特にレアギンの証明とその臨 本的意義，最新医学，18(3)，516，1963，21）北原 静夫：アレルギー疾患の臨床，日本医事新報，2008， 7，1962，22）北村武，线野佳德：アレルギー性鼻炎 患者に批けるアレルゲン抽出液使用経験について，取院 科，35 (8)，669，1963．23）小口昌美，内木久郎： 急性春季カタルの提唱及び本疾患之花粉との関係，日医 大誌，21，8，597，1954。24) 佐藤靖雄，寺尾樹： 花粉症，耳展，2，8，9，1965。25）杉田和春，降矢 和夫：花粉症の研究，I アレルギー，13 $(1,2), 19$ ， 1964。26）田多井吉之介, 長田泰公：好酸球の動力 学, 医学書院, 東京, 1956 .27) 桥本泰浐, 古内一郎 他：アレルギー性鼻炎に拉けるブタクサ花粉 Ragweed pollen の検討，耳喉科，37，1，83，1965，28) 林義

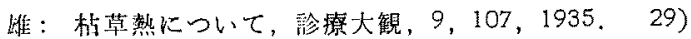
藤沢康武：フレルギー性鼻疾患に関する臨床的研究， 日耳鼠，42，2，1936。30）堀口申作，玟藤洋三：ア レルギー性奥炎における察咽腔炎の意義について，日耳 点, $65,12,1368,1962$.31) 䏱口电作, 斎藤洋三:

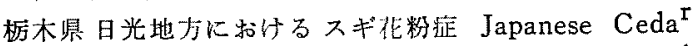
Pollinosis の発見，アレルギー。13 $(1,2) ， 16,1964^{\circ}$ 32）堀口申作, 卤藤洋三：鼻アレルギーに括けるアレ ルゲンエキス皮内反応の臨床的研究（1），検查基㳃の检 尌、アレルギー、14(2)，18，1965.33) 堀口申作,

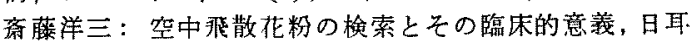
鼻，68，8，974，1965.34）煀口申作，斎藤洋三： T

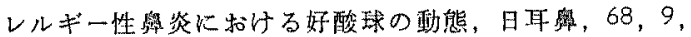
1965.35）牧野富太郎：日本植物図鑑，北隆館，東 京. 36）山中幸造：楀腔に猢る北粉アレルギーの 実験的研究，日耳莮，49，323，1943。

本諭文の要旨は下記学会に括いて発表した。第13 回日本アレルギー学会総会 $(1963 ， 10$. 神戸), 第 45回日耳䦩柬地方会大会 (1964，3。東京)，第65 回日本耳鼻咽喉科学会総会 $(1964,5$. 德岛).

（原稿到着=炤和 40.6 .11 日） 